\title{
Presence of necrotic strains of Potato virus $Y$ in Mexican potatoes
}

Victoriano Roberto Ramírez-Rodríguez ${ }^{1}$, Gustavo Frías-Treviño ${ }^{2}$, Katia AviñaPadilla $^{1}$ and Juan Pablo Martínez-Soriano*1

Address: ${ }^{1}$ Centro de Investigación y de Estudios Avanzados del Instituto Politécnico Nacional, Campus Guanajuato, km. 9.6 libramiento norte, carretera Irapuato-León, 36821 Irapuato, Guanajuato, Mexico and ${ }^{2}$ Universidad Autónoma Agraria Antonio Narro, Departamento de Parasitología. Buenavista, Saltillo, Coahuila, Mexico

Email: Victoriano Roberto Ramírez-Rodríguez - vicr358@yahoo.com; Gustavo Frías-Treviño - friast@yahoo.com.mx; Katia Aviña-

Padilla - kap@ira.cinvestav.mx; Juan Pablo Martínez-Soriano* - jpms@ira.cinvestav.mx

* Corresponding author

Published: 18 June 2009

Virology Journal 2009, 6:80 doi:10.1186/1743-422X-6-80
Received: 17 June 2009

Accepted: 18 June 2009

This article is available from: http://www.virologyj.com/content/6/I/80

(c) 2009 Ramírez-Rodríguez et al; licensee BioMed Central Ltd.

This is an Open Access article distributed under the terms of the Creative Commons Attribution License (http://creativecommons.org/licenses/by/2.0), which permits unrestricted use, distribution, and reproduction in any medium, provided the original work is properly cited.

\section{Abstract}

Correction to Ramírez-Rodríguez VR, Frías-Treviño G, Aviña-Padilla K, Silva-Rosales L, MartínezSoria JP: Presence of necrotic strains of Potato virus $Y$ in Mexican potatoes. Virology Journal 2009, $6: 48$ 


\section{Correction}

The published version of this article [1] included Dr SilvaRosales in the author list. Dr Silva-Rosales was not involved in the detailed process of this manuscript, and has requested to be removed from the author list. Therefore, we are removing Dr Silva-Rosales as an author; a corrected author list has been provided with this Correction.

\section{References}

I. Ramírez-Rodríguez VR, Frías-Treviño G, Aviña-Padilla K, SilvaRosales L, Martínez-Soria JP: Presence of necrotic strains of Potato virus $Y$ in Mexican potatoes. Virology Journal 2009, 6:48.

Publish with Bio Med Central and every scientist can read your work free of charge

"BioMed Central will be the most significant development for disseminating the results of biomedical research in our lifetime. " Sir Paul Nurse, Cancer Research UK

Your research papers will be:

- available free of charge to the entire biomedical community

- peer reviewed and published immediately upon acceptance

- cited in PubMed and archived on PubMed Central

- yours - you keep the copyright 